University of Nebraska - Lincoln

DigitalCommons@University of Nebraska - Lincoln

U.S. Department of Veterans Affairs Staff

Publications

U.S. Department of Veterans Affairs

2010

\title{
GHRH antagonists reduce the invasive and metastatic potential of human cancer cell lines in vitro
}

\author{
Szabolcs Bellyei \\ University of Miami, bellyeisz@gmail.com \\ Andrew V. Schally \\ University of Miami \\ Marta Zarandi \\ University of Miami \\ Jozsef L. Varga \\ University of Miami \\ Irving Vidaurre \\ South Florida Veterans Affairs Foundation for Research and Education \\ See next page for additional authors
}

Follow this and additional works at: https://digitalcommons.unl.edu/veterans

Bellyei, Szabolcs; Schally, Andrew V.; Zarandi, Marta; Varga, Jozsef L.; Vidaurre, Irving; and Pozsgai, Eva, "GHRH antagonists reduce the invasive and metastatic potential of human cancer cell lines in vitro" (2010). U.S. Department of Veterans Affairs Staff Publications. 27.

https://digitalcommons.unl.edu/veterans/27

This Article is brought to you for free and open access by the U.S. Department of Veterans Affairs at DigitalCommons@University of Nebraska - Lincoln. It has been accepted for inclusion in U.S. Department of Veterans Affairs Staff Publications by an authorized administrator of DigitalCommons@University of Nebraska - Lincoln. 


\section{Authors}

Szabolcs Bellyei, Andrew V. Schally, Marta Zarandi, Jozsef L. Varga, Irving Vidaurre, and Eva Pozsgai 


\title{
GHRH antagonists reduce the invasive and metastatic potential of human cancer cell lines in vitro
}

\author{
Szabolcs Bellyei ${ }^{\mathrm{a}, \mathrm{b}, *}$, Andrew V. Schally ${ }^{\mathrm{a}, \mathrm{b}}$, Marta Zarandi ${ }^{\mathrm{a}, \mathrm{b}}$, Jozsef L. Varga ${ }^{\mathrm{a}, \mathrm{b}}$, \\ Irving Vidaurre ${ }^{\mathrm{a}}$, Eva Pozsgai ${ }^{\mathrm{a}, \mathrm{b}}$ \\ ${ }^{a}$ Veterans Affairs Medical Center and South Florida Veterans Affairs Foundation for Research and Education, Miami, FL 33125, USA \\ ${ }^{\mathrm{b}}$ Department of Pathology, Department of Medicine, University of Miami, Miller School of Medicine, Miami, FL 33125, USA
}

\section{A R T I C L E I N F O}

\section{Article history:}

Received 18 October 2009

Received in revised form 13 December 2009

Accepted 17 December 2009

\section{Keywords:}

GHRH antagonist

Invasion

Metastasis

MMP

$\mathrm{NF}-\mathrm{\kappa B}$

\begin{abstract}
A B S T R A C T
We investigated the effect of a GHRH antagonist, MIA-602 on the metastatic cascade in vitro of three human cancers, DBTRG-05 glioblastoma, MDA-MB-468 estrogen-independent breast, and ES-2 clear cell ovarian cancer. GHRH receptors and their main splice variant, SV1 were detected on all three cell lines. After treatment with MIA-602, the cell viability decreased significantly, significant inhibition of cell invasion was observed and the release of MMPs was significantly decreased. The attachment of cancer cells to fibronectin and matrigel was severely hindered. Wound-healing experiments demonstrated a reduced cellular motility in all three cell lines. The upregulation of caveolin-1 and E-cadherin, and the powerful downregulation of NF- $\kappa \mathrm{B}$ and $\beta$-catenin was detected. Our study suggests that the clinical application of highly potent GHRH antagonists in cancer therapy would be desirable since they inhibit proliferation and metastasis development as well.
\end{abstract}

(c) 2009 Elsevier Ireland Ltd. All rights reserved.

\section{Introduction}

Breast cancer, the most common cancer among women worldwide, and malignant glioma, constitute international major health problems, because of their aggressive metastatic behavior or angiogenicity [1-3]. Bone metastases, hypercalcaemia and fractures lead to increased morbidity and mortality in patients with breast cancer [3]. Ovarian cancer, one of the least curable malignancies and fourth most frequent cause of cancer-related mortality among women in the Western world, likewise poses a problem for treatment due to its usually advanced stage at the time of diagnosis [4,5]. New treatment modalities for the metastases of all three cancers must be explored.

\footnotetext{
* Corresponding author. Address: Veterans Affairs Medical Center and South Florida Veterans Affairs Foundation for Research and Education, 1201 Northwest 16th street, Research(151), Room 2A103C Miami, FL 33125, USA. Fax: +1 3055753126 .

E-mail address: bellyeisz@gmail.com (S. Bellyei).
}

Antagonists of growth hormone-releasing hormone (GHRH) have been tested for the treatment of different types of experimental tumors, including malignant gliomas [6], breast cancer [7] and ovarian cancer [8]. GHRH, a peptide hormone secreted by the hypothalamus, stimulates the secretion of growth hormone $(\mathrm{GH})$ after binding to pituitary-type GHRH receptors (pGHRH-R) on the anterior pituitary $[9,10]$. GH stimulates the production of the insulin-like growth factor I (IGF-I), which plays a crucial role in malignant transformation, metastasis and tumorigenesis in various cancers [11-15]. The presence of pGHRH-R and its splice variant with a high structural homology to pGHRH-R, SV1, on DBTRG-05 glioblastoma and MDA-MB-468 breast cancer cell lines has been previously demonstrated [16,17]. GHRH antagonists inhibit the secretion of $\mathrm{GH}$ and block the binding of autocrine GHRH to receptors on tumor cells, thus suppressing the hepatic production of IGF-I [7,11,18-24]. GHRH antagonists have been shown to be successful in the experimental therapy of glioblastomas, and their passage across the 
blood-brain barrier and accumulation in the brain have been demonstrated previously [25].

The inhibitory effects of GHRH antagonists on tumor growth, invasion and metastatic ability of various cancers in vivo have also been investigated [20,26,27]. Promising results in the metastatic experimental models of estrogen-independent breast cancer [20], androgen-independent prostate-cancer [26] and renal cell carcinoma were obtained with earlier GHRH antagonists [27]. However, the actions of the new GHRH antagonist, MIA-602 on metastatic potential, and cellular mechanisms affected, have not yet been described. In our in vitro study in three highly malignant cell lines glioblastoma, estrogen-independent breast cancer and ovarian cancer cell lines, it was our goal to demonstrate how MIA-602 affects the critical steps of malignant tumorigenesis, such as cell proliferation, stimulation of angiogenesis, enhancement of cell motility, cellular invasion and the production of key proteins involved in metastasis development.

\section{Materials and methods}

\subsection{Peptides and chemicals}

GHRH antagonist MIA-602 was synthesized in our laboratory by solid-phase method and purified by reversedphase HPLC as described previously [28]. The chemical structure of MIA-602 is [(PhAc-Ada $)^{0}-\mathrm{Tyr}^{1}, \mathrm{D}-\mathrm{Arg}^{2}, \mathrm{Fpa}^{6}{ }^{6}$, Ala $^{8}, \operatorname{Har}^{9}, \operatorname{Tyr}(\mathrm{Me})^{10}, \mathrm{His}^{11}, \operatorname{Orn}^{12}, \mathrm{Abu}^{15}, \mathrm{His}^{20}, \mathrm{Orn}^{21}$, $\left.\mathrm{Nle}^{27}, \mathrm{D}-\mathrm{Arg}^{28}, \mathrm{Har}^{29}\right] \mathrm{hGH}-\mathrm{RH}(1-29) \mathrm{NH}_{2}$. Non-coded amino acids and acyl groups used in the antagonists are abbreviated as follows: Abu, $\alpha$-aminobutyric acid; Ada, 12aminododecanoic acid; Fpa5, pentafluoro-phenylalanine; Har, homoarginine; Nle, norleucine; Orn, ornithine; PhAc, phenylacetyl; Try(Me), O-methyl-tyrosine. For the experiments the GHRH antagonist was dissolved in 0.1\% DMSO and diluted with incubation media.

\subsection{Cell lines}

The human cell lines (DBTRG-05 glioblastoma, MDAMB-468 estrogen-independent breast cancer, and ES-2 clear cell ovarian cancer) were obtained from American Type Culture Collection (Manassas, VA, USA) and cultured at $37^{\circ} \mathrm{C}$ in a humidified 95\% air/5\% CO2 atmosphere. DBTRG-05 cells were cultured in RPMI-1640 supplemented with antibiotics/antimycotics, 10\% FBS and HEPES. MDAMB-468 cells were cultured in DMEM and ES-2 cells in McCoy's 5A, supplemented with antibiotics/antimycotics and $10 \%$ FBS. The culture media were purchased from GIBCO (Carlsbad, CA).

\subsection{Cell viability assay}

Cells were seeded onto 96-well-plates at a starting density of 2500 cells/well, cultured overnight, starved for $24 \mathrm{~h}$ with medium containing no FBS and then treated with $1 \mu \mathrm{M}$ GHRH antagonist MIA-602 for $48 \mathrm{~h}$. After the treatment the relative number of viable cells were measured in comparison with the untreated control and the solvent control using Cell Titer 96 AQueusus Assay (Promega) according to the manufacturer's instructions at $490 \mathrm{~nm}$ in a Victor3 multilabel counter (Perkin-Elmer, Waltham, MD, USA). All experiments were run at least in quadruplicate and repeated three times. The percentage of cell survival was determined by comparing the absorbance value of the vehicle control.

\subsection{Adhesion assay}

The adhesion assay was performed by MTT assay. All three cell lines were starved for $24 \mathrm{~h}$ with medium containing no FBS. Then monolayers of the cell lines $\left(1 \times 10^{5}\right)$ were incubated with or without $1 \mu \mathrm{M}$ GHRH antagonist MIA-602 for $24 \mathrm{~h}$. Subsequently, the cells were planted into the fibronectin precoated $(10 \mu \mathrm{g} / \mathrm{ml})$ and matrigel precoated $(100 \mu \mathrm{g} / \mathrm{ml})$ 96-well plate in triplicate. The groups of cells were washed at $30 \mathrm{~min}, 60 \mathrm{~min}$ and $90 \mathrm{~min}$, respectively, to remove the non-adherent cells. After washing, the adhered cells were measured by MTT assay at $490 \mathrm{~nm}$. The OD values of washed groups compared with those of non-washing groups reflect the proportion of cells adhered to the fibronectin and matrigelcoated 96-well plate.

\subsection{Gelatin zymography}

DBTRG-05, MDA-MB-468, and ES-2 cell lines were starved for $24 \mathrm{~h}$ with medium containing no FBS. Subsequently, the cells in media containing $0.5 \%$ FBS were stimulated with $1 \mu \mathrm{M}$ GHRH antagonist MIA-602 for different time periods and then, the supernatants were collected. The samples were analyzed with gelatin zymography, $(0.1 \% \mathrm{w} / \mathrm{v})$ gelatin (Sigma) as the substrate. Each lane was loaded with a total protein concentration of $3 \mu \mathrm{g}$ and subjected to SDS-PAGE electrophoresis at $48^{\circ} \mathrm{C}$. Gels were washed twice in $50 \mathrm{mM}$ Tris ( $\mathrm{pH} 7.4)$ containing $2.5 \%(\mathrm{v} / \mathrm{v})$ Triton X-100 for $1 \mathrm{~h}$, followed by two 10-min rinses in $50 \mathrm{mM}$ Tris (pH 7.4). After SDS removal, the gels were incubated overnight in $50 \mathrm{mM}$ Tris ( $\mathrm{pH} 7.5)$ containing $10 \mathrm{mM}$ $\mathrm{CaCl}_{2}, 0.15 \mathrm{M} \mathrm{NaCl}, 0.1 \%$ (v/v) Triton X-100, and $0.02 \%$ sodium azide at $37{ }^{\circ} \mathrm{C}$ under constant gentle shaking. After incubation, the gels were stained with $0.25 \%$ Coomassie brilliant blue R-250 (Sigma) and destained in 7.5\% acetic acid with $20 \%$ methanol. The gelatinase bands appeared white on a blue background. The activity of metalloproteinases MMP-2 and MMP-9 was determined semiquantitatively by densitometry.

\subsection{Isolation of subcellular fractions}

Cells were harvested and low-speed centrifuged, then the pellet was dispersed by vortexing in lysis buffer (50 mM Tris- $\mathrm{HCl}$ ( $\mathrm{pH}^{1 / 4}$ 8.0), 1\% Triton X-100, 10\% glycerol, $1 \mathrm{mM}$ EDTA, $250 \mathrm{mM} \mathrm{NaCl}, 1 \mathrm{mM}$ dithiothreitol, $1 \mathrm{mM}$ phenylmethylsulfonylfluoride, $2 \mathrm{mM}$ sodium vanadate, $100 \mathrm{mM}$ sodium fluoride, $10 \mathrm{mg} / \mathrm{ml}$ aprotinin, $10 \mathrm{mg} / \mathrm{ml}$ leupeptin and $10 \mathrm{mg} / \mathrm{ml}$ pepstatin) for $10 \mathrm{~min}$ at $4{ }^{\circ} \mathrm{C}$. Isolation of cytosol, nuclear and mitochondrial fractions was carried out by standard lab protocols exactly as described previously [29]. 


\subsection{Western blot}

Cells were washed with PBS, and directly lysed in lysis buffer. Cell lysates were adjusted to equal protein concentrations (NanoDrop Technologies, Inc., Wilmington, DE), resuspended in $2 \times$ sample loading buffer containing $4 \%$ SDS, 20\% glycerol, $120 \mathrm{mM}$ Tris and bromophenol blue, and were boiled for $5 \mathrm{~min}$. Protein samples were subjected to SDS-polyacrylamide gel electrophoresis. Proteins on the gel were transferred onto nitrocellulose membranes that were blocked with 50-50\% Odyssey buffer and phosphate buffered saline (PBS) for $1 \mathrm{~h}$ at room temperature. Afterwards, the membranes were incubated with the indicated primary antibodies overnight at $4^{\circ} \mathrm{C}$. Primary antibody for GHRH-R was purchased from Abcam (ab28692, Abcam Inc., Cambridge, MA). E-cadherin, caveolin-1, $\beta$-catenin primary antibodies were purchased from Cell Signaling. NF- $\kappa B$ and MMP-2 primary antibodies were purchased from Santa Cruz Biotechnology, Inc. Alpha-tubulin primary antibody was obtained from Calbiochem. After being washed with PBS containing $0.1 \%$ Tween-20, the membranes were incubated with the appropriate secondary antibody. The immunoreactive bands were visualized with the Odyssey Infrared Imaging System (Li-COR Biosciences, Lincoln, Nebraska).

\subsection{Wound migration assay}

DBTRG-05, MDA-MB-468, and ES-2 cells $\left(2 \times 10^{5}\right)$ were seeded into six-well plates and grown to $100 \%$ confluency. After starvation of the cells, the confluent cells were carefully wounded with sterile polished pasteur pipette tips and any cellular debris were removed by washing with PBS. The wounded monolayers were then incubated in the presence of $1 \mu \mathrm{M}$ MIA-602 for $6 \mathrm{~h}$ and $24 \mathrm{~h}$ and digitally photographed. The distance between the wound edges was measured using Adobe Photoshop 6.0.

\subsection{Invasion assay}

Cell migration assays were performed according to the manufacturer's protocol. The BD Falcon Cell Culture Insert System containing PET (polyethylene terephthalate) mem- branes with $8 \mu \mathrm{m}$ pores (BD Biosciences Discovery Labware Franklin Lakes, $\mathrm{NJ}$ ) was utilized in the assay. DBTRG-05, MDA-MB-468, and ES-2 cells were harvested, after a $24 \mathrm{~h}$ starving period, and resuspended into serumfree medium containing $1.0 \mu \mathrm{M}$ GHRH antagonist or the vehicle. The upper chamber of the insert was filled with $500 \mu \mathrm{l}$ of the cell and drug suspension $\left(1 \times 10^{5}\right.$ cells $)$ and $1.5 \mathrm{ml}$ of fibroblast-conditioned medium (FCM) was added to the lower chamber. FCM served as the chemoattractant. The conditioned medium was collected from NIH/3T3 cells grown in serum-free DMEM after $24 \mathrm{~h}$. The plate was incubated in a humidified environment at $37{ }^{\circ} \mathrm{C}$ with $5 \% \mathrm{CO}_{2}$ for $24 \mathrm{~h}$. Cells were allowed to migrate or invade for $24 \mathrm{~h}$. Cells that had not penetrated the filters were removed by scrubbing with cotton swabs. Chambers were fixed in $100 \%$ methanol for $10 \mathrm{~min}$, stained in $0.5 \%$ crystal violet for $10 \mathrm{~min}$, rinsed in PBS and examined under a bright-field microscope. Values for invasion and migration were obtained by counting five fields per membrane. Our results represent the average of three independent experiments performed over multiple days.

\subsection{Data analysis}

Quantification of band density was performed using the Odyssey Infrared Imaging System (Li-COR Biosciences, Lincoln, Nebraska). Data shown in the figures are representative of at least three different experiments. Results are expressed as means \pm SEM. Results were compared using Student's $t$ test (two-tailed). Differences were considered statistically significant when $P<0.05$. $P$ values shown are against the control group.

\section{Results}

3.1. The presence of $p G H R H-R$ and its splice variant, SV1 on DBTRG-05, MDA$M B-468$ and $E S-2$ cell lines

We investigated whether pGHRH-R and SV1 are present on all three cell lines using Western blot method. SV1 of GHRH-R has the greatest structural similarity to the pGHRH-R and is considered the main truncated splice variant [30]. For the detection, we used polyclonal antiserum against the polypeptide segment, found in both pGHRH and SV1 receptors. Both types of receptors were detected on all three cancer cell lines,

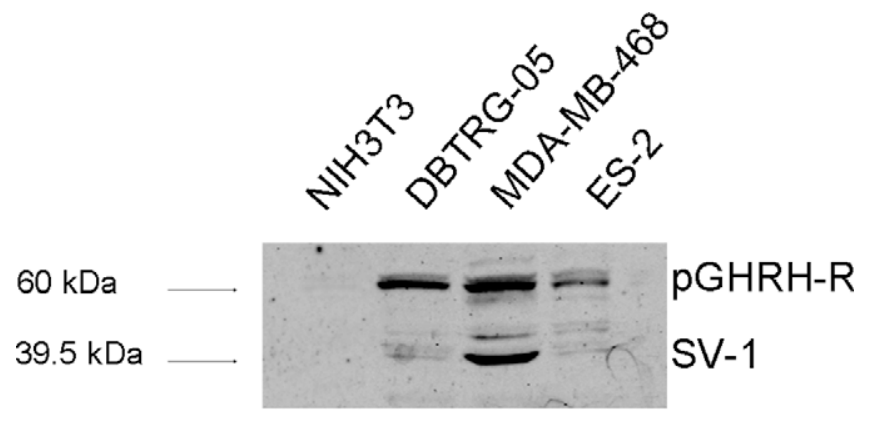

a-tubulin

Fig. 1. Western blot analysis of pGHRH-R and SV1, with $\alpha$-tubulin as control in samples from NIH/3T3, DBTRG-05, MDA-MB-468 and ES-2 cell lines. All immunoreactive signals were detected with a commercial polyclonal antiserum against a polypeptide segment that is present in both SV1 and pGHRH receptors. The molecular masses are shown. 


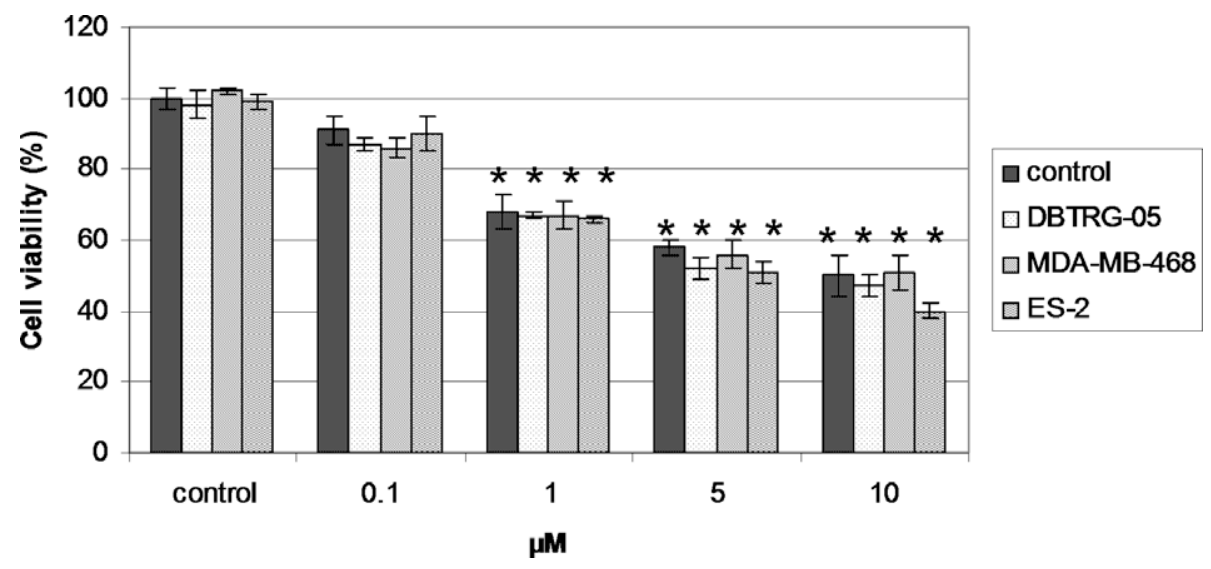

Fig. 2. The inhibitory effect of GHRH antagonist MIA-602 on cell viability of DBTRG-05, MDA-MB-468 and ES-2 in different concentrations. Cell viabilities were measured by an methylthiazolydiphenyl-tetrazolium bromide MTT assay and were expressed as percentage of untreated cells of three independent experiments performed at least in quadruplicate. Vertical bars represent SEM. ${ }^{*} P<0.05$.

pGHRH-R at $60 \mathrm{kDa}$ and SV1 at $39.5 \mathrm{kDa}$, although both receptors were expressed at the highest level in MDA-MB-468 cells, and at a lesser extent in the other two cell lines. pGHRH-R was expressed at a significantly higher level than SV1 in all three cell lines. (Fig. 1) Our results correspond to earlier findings on pGHRH-R and SV1 detection [16,17,31]. NIH/3T3 cells were used as a negative control since they express neither pGHRH nor SV1 receptors [32].

\subsection{The inhibitory effect of GHRH antagonist MIA-602 on cell viability}

DBTRG-05, MDA-MB-468 and ES-2 cancer cell lines, were exposed to GHRH antagonist, MIA-602 at $0.1,1,5$ and $10 \mu \mathrm{M}$ concentrations for $48 \mathrm{~h}$. The untreated cells served as negative controls. MIA-602 inhibited cell viability at all concentrations. Since the concentration, at which cellular growth was inhibited by $30 \%$ (IC 30 ), was $1 \mu \mathrm{M}$, we used this concentra-

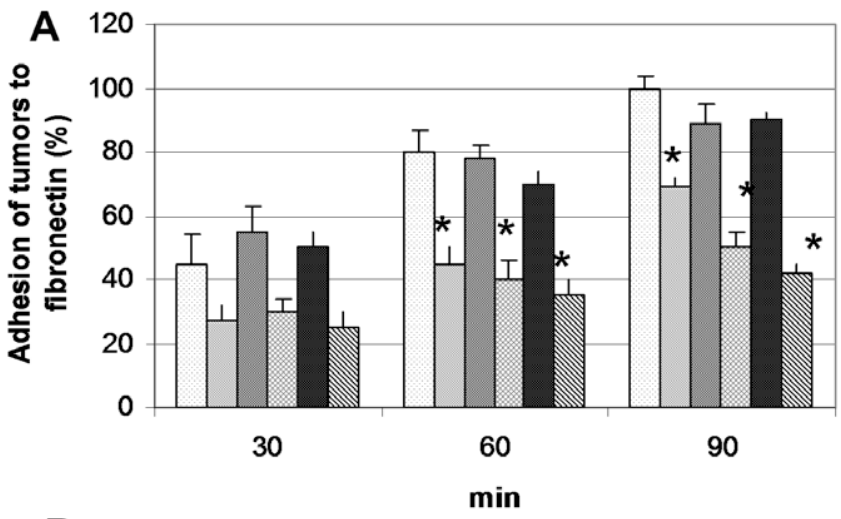

\section{口DBTRG-05 \\ 口DBTRG-05+MIA-602 \\ $\square$ MDA-MB-468 \\ $\square$ MDA-MB-468+MIA-602 \\ $\square \mathrm{ES}-2$ \\ $\mathbb{B} \mathrm{ES}-2+\mathrm{MIA}-602$}

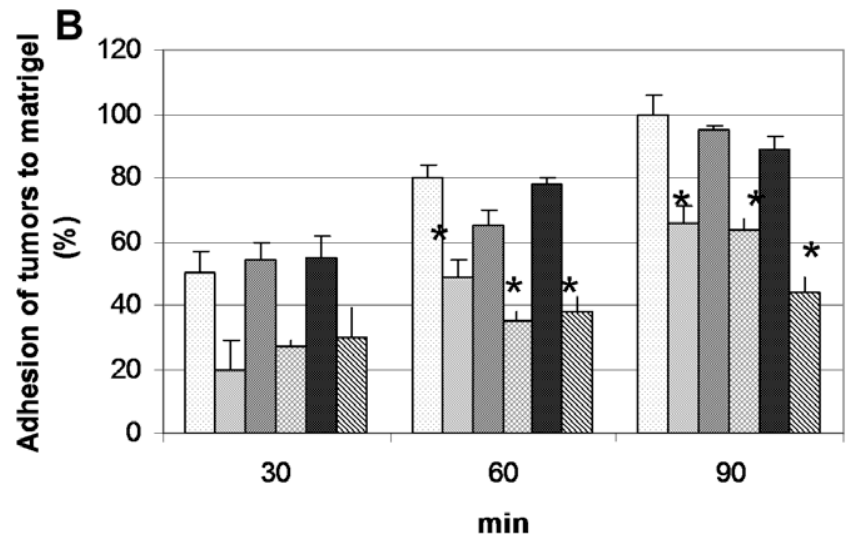

\section{$\square$ DBTRG-05 \\ $\square$ DBTRG-05+MIA-602 \\ $\square \mathrm{ES}-2$ \\ ๑ $\mathrm{Es}-2+\mathrm{MIA}-602$ \\ - MDA-MB-468 \\ MDA-MB-468+MIA-602}

Fig. 3. The effect of GHRH antagonist MIA-602 on the adhesion of DBTRG-05, MDA-MB-468 and ES-2. Cells were incubated with or without $1 \mu \mathrm{M}$ MIA-602 and seeded onto 96-well plates precoated with: (A) fibronectin or (B) matrigel. The remaining cells per well were measured after 30, 60 and 90 min. Data were representative of three separate experiments. Vertical bars represent SEM. ${ }^{*} P<0.05$. 
tion in our experiments further on in our study. After treatment with $1 \mu \mathrm{M}$ MIA-602 the cell viabilities decreased significantly, by $34 \%$ in DBTRG-05 cells, by $30 \%$ in MDA-MB-468 cells and by $32 \%$ in ES-2 cells (Fig. 2).

\subsection{Inhibitory effects of MIA-602 on cancer cell adhesion}

The increased cell adhesion to the extracellular matrix (ECM) is considered an important step in the acquisition of metastatic properties in cancer cells. Cell adhesion assays were used to determine the ability of the tumor cells to bind ECM components. All three cell lines were treated with the GHRH antagonist then added to fibronectin precoated plates and allowed to adhere for 30, 60 and $90 \mathrm{~min}$. Compared to the controls, all three cells showed significantly decreased attachment to fibronectin. At 90 min the adhesion ratio of DBTRG-05, MDA-MB-468 and ES-2 decreased significantly, by 30\%, 34\% and 54\%, respectively (Fig. 3a). Following the treatment, when the tumor cells were added to matrigel precoated plates, similar results were observed. The adhesion ratio to matrigel diminished in DBTRG-05 cells by 34\%, in MDA-MD-468 cells by $31 \%$ and in ES- 2 cells by $51 \%$ (Fig. 3 b).

\subsection{Inhibition of tumor cell invasion by MIA-602}

A major issue of metastasis development is the invasion of tumor cells into surrounding tissues. Invasion chambers with matrigel-coated membranes were used to investigate the invasive properties of untreated (control) and GHRH antagonist treated cells. The average invasion rate of all three cancer cell lines (DBTRG-05, MDA-MB-468 and ES-2) decreased significantly after $24 \mathrm{~h}$ of exposure to MIA-602 compared to untreated cells (Fig. 4). ES-2 cells showed the greatest reduction in their invasion rate following treatment, compared to the other two cell lines.

\subsection{Inhibition of cell motility by MIA-602}

Another measure of the metastatic potential of cancer cells is their increased motility. In order to examine, whether exposure to GHRH antagonist, MIA-602 affected the motile ability of the cells, we performed wound-healing assays. Wound closure was examined at 12 and $24 \mathrm{~h}$ following treatment. The control cells migrated into the wound area by $24 \mathrm{~h}$ to an extent that the wound edges were undistinguishable (Fig. 5a). However, cells, from all three cell lines, treated with the GHRH antago-
A
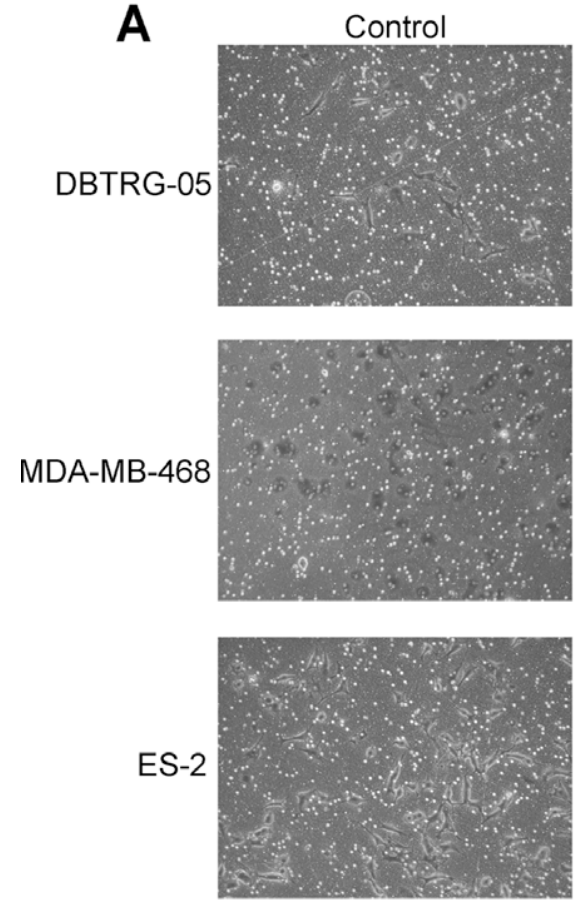

MIA-602 $(1 \mu \mathrm{M} 24 \mathrm{hr})$
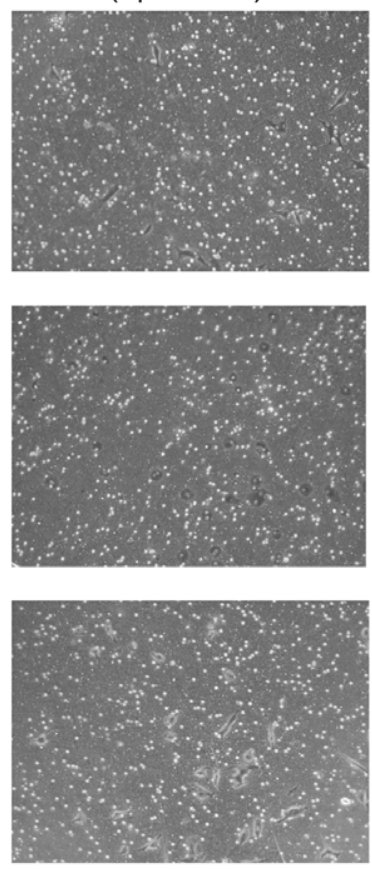

B

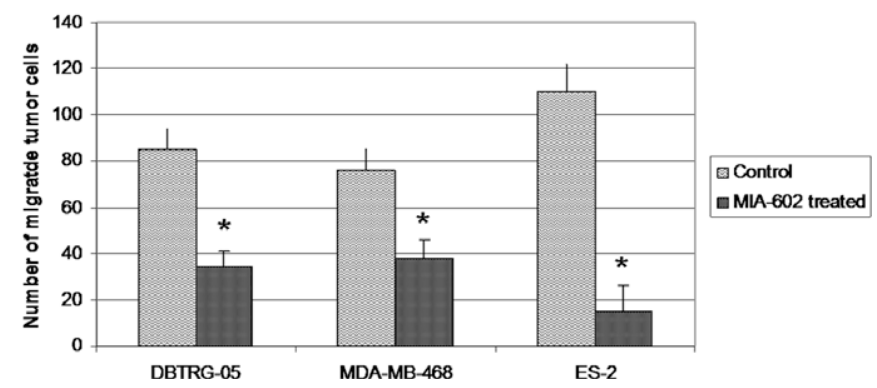

Fig. 4. The effect of GHRH antagonist MIA-602 on the invasion of DBTRG-05, MDA-MB-468 and ES-2 in vitro. (A) Photomicrographs show the invasion of the cells through the layer of membrane and images were taken under $40 \times$ magnification. (B) Migration of cells through $8 \mu \mathrm{m}$ Matrigel-coated polycarbonate pores was determined by the Boyden chamber model. Cells not exposed to MIA-602 were used as a control. Vertical bars represent SEM. ${ }^{*}<<0.05$. 


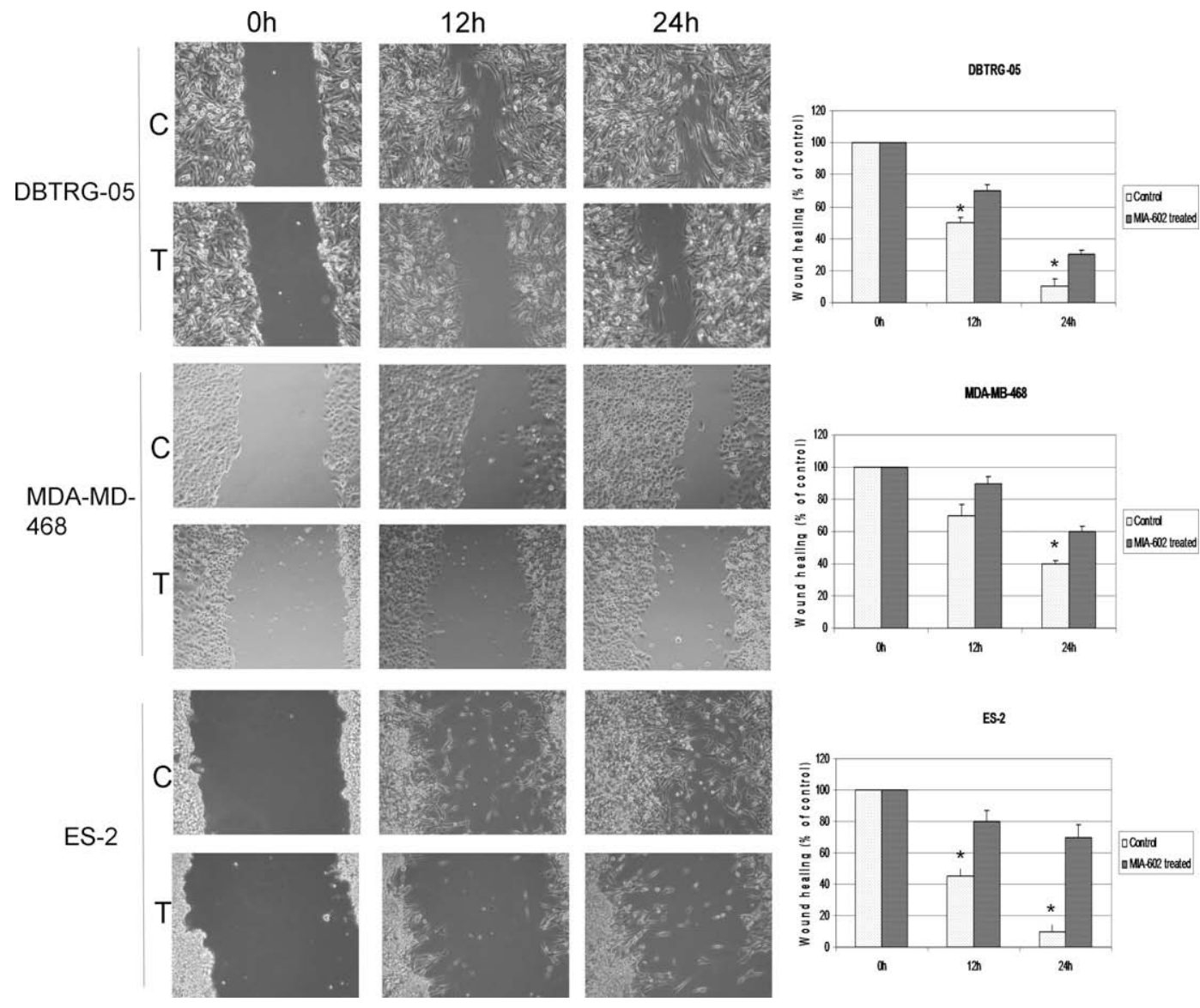

Fig. 5. The effect of GHRH antagonist MIA-602 on the cell motility of DBTRG-05, MDA-MB-468 and ES-2 demonstrated by wound-healing assays. Confluent cells cultured in six-well dishes were wounded with a sterile pipette tip and then incubated with or without $1 \mu \mathrm{M}$ MIA-602 for $0 \mathrm{~h}, 12 \mathrm{~h}$ and $24 \mathrm{~h}$ (C: control; T: treated). Photographs were taken with inverted microscope (Olympus CKX41) under $40 \times$ magnification and measurements were made with Adobe photoshop 6.0. Representative monolayer images are shown. Vertical bars represent SEM. ${ }^{*} P<0.05$.

nist, displayed significantly slower wound closure at both time points, never completely closing the wound area (Fig. 5b). The motility of ES-2 cells was inhibited most by the GHRH antagonist, compared to the other two cell lines.

\subsection{The effect of MIA-602 on the expression of adhesion, proliferation and invasion-associated molecules}

We used immunoblotting to determine the expression of cell adherens junction proteins (1), caveolin-1, E-cadherin and $\beta$-catenin following 6,24 and $48 \mathrm{~h}$ of MIA-602 treatment. Following $6 \mathrm{~h}$ of treatment the levels of caveolin-1 and E-cadherin were significantly elevated and steadily rose, peaking at $24 \mathrm{~h}$ in all three cancer cell lines (DBTRG-05, MDAMB-468 and ES-2) (Fig. 6a). On the other hand, $\beta$-catenin levels were dramatically reduced after MIA-602 treatment, reaching their lowest level at $24 \mathrm{~h}$ (Fig. $6 \mathrm{~b}$ ). The expression of NF- $\mathrm{KB}$, a protein involved in the regulation of cellular survival, proliferation and carcinogenesis [33], was examined in the cell, cytosol and nuclear lysate of the three cancer cells after exposure to MIA-602. The GHRH antagonist treated cells showed decreased NF- $\mathrm{KB}$ nuclear translocation and increased cytosolic expression, which indicates the potent inhibition of NF- $\kappa B$ activation by MIA-602. One of the important downstream effectors of NF- $\kappa B$, MMP2 , [33,34] plays a pivotal role in tumor invasion [35]. Using Western blot analysis, we detected the significant reduction of MMP-2 expression in MIA-602 treated cells (Fig. 6c). Results were similar in all three cell lines.

\subsection{The inhibitory effect of MIA-602 on MMP-2 and MMP-9 expression}

MMP-2 and MMP-9 are extracellular metalloproteinases which influence cell motility and invasion and are often upregulated in cancers [36]. The activity of these two matrix-metalloproteinases was investigated using gelatin zymography. Cells were treated with MIA-602 for 6, 12, 24 and $48 \mathrm{~h}$, then their supernatants were collected and the MMP activity measured. A gradual decrease in the activities of both MMP-2 and MMP-9 was observed from the first time point $(6 \mathrm{~h})$, and was the lowest after $48 \mathrm{~h}$ of treatment in all three cell lines (DBTRG-05, MDA-MB-468 and ES-2) indicating the potent inhibitory effect of MIA-602 (Fig. 7).

\section{Discussion}

The prognosis of cancer patients is strongly correlated with the stage of the cancer at the initial diagnosis. Patients afflicted by advanced stage ovarian or breast cancer have poor prognosis and a low survival rate, since these tumors show increased invasiveness and metastatic ability [37,38]. Malignant glioblastomas are particularly aggressive, highly angiogenic and considered to be incurable $[1,39,40]$. In our study, we conducted our experiments with representative cell lines from malignant glioma, breast and ovarian cancer: DBTRG-05 glioblastoma, MDA- 

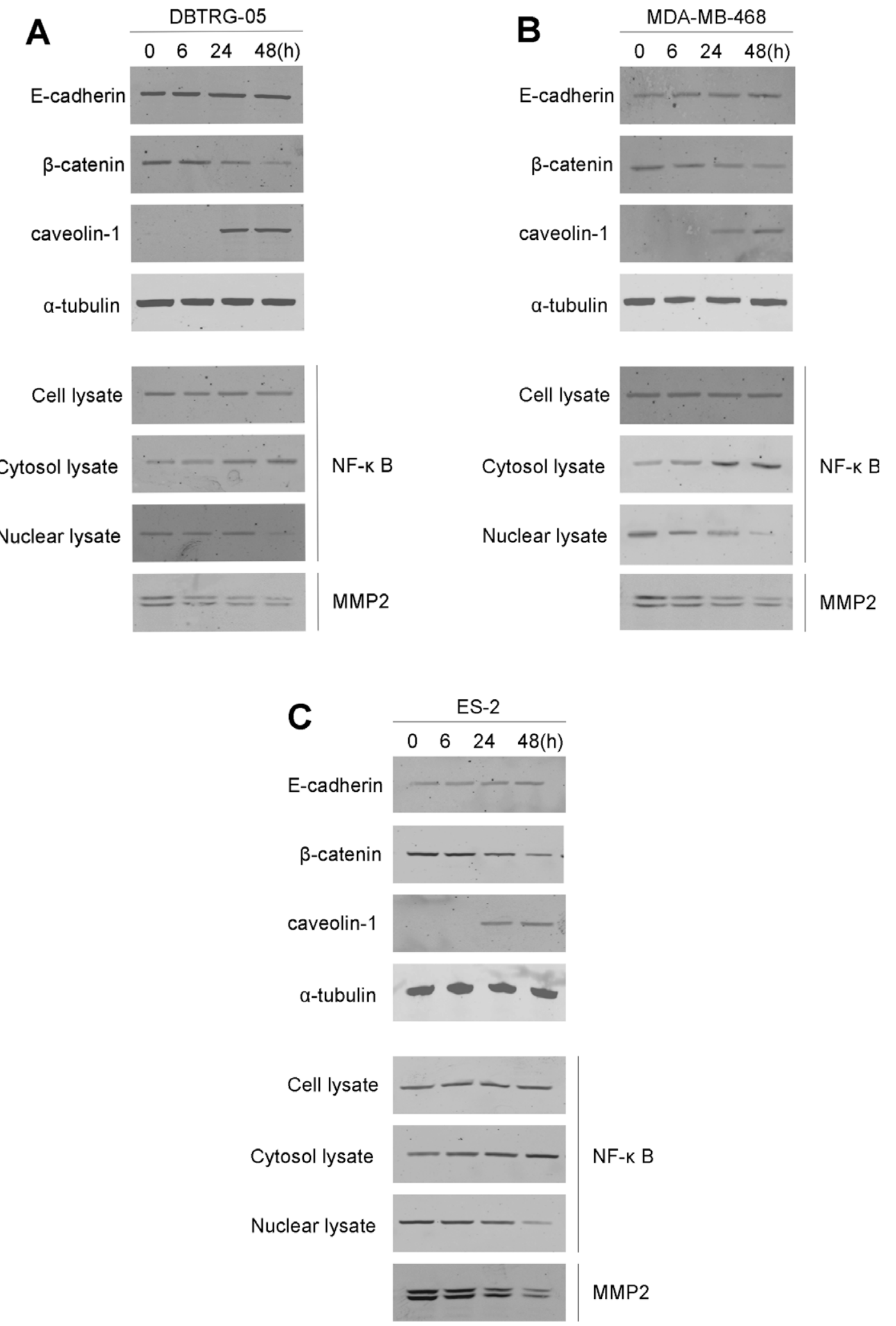

NF-K B

MMP2

Fig. 6. The effect of GHRH antagonist MIA-602 on the activation of E-cadherin, caveolin-1 and inhibition of $\beta$-catenin, NF- $\kappa \mathrm{B}$ and MMP-2 activity on: (A) DBTRG-05 (B) MDA-MB-468 and (C) ES-2 cell lines. The cells were collected at the indicated time points after being treated with $1 \mu \mathrm{M}$ MIA-602 and were analyzed by Western blot. The protein levels of NF- $\kappa B$ were analyzed in whole lysates, cytosol and nucleus by immunoblot to confirm the translocation. $\alpha$ tubulin immunoreactivity was used to show even loading. Representative blots of three independent experiments are presented. 

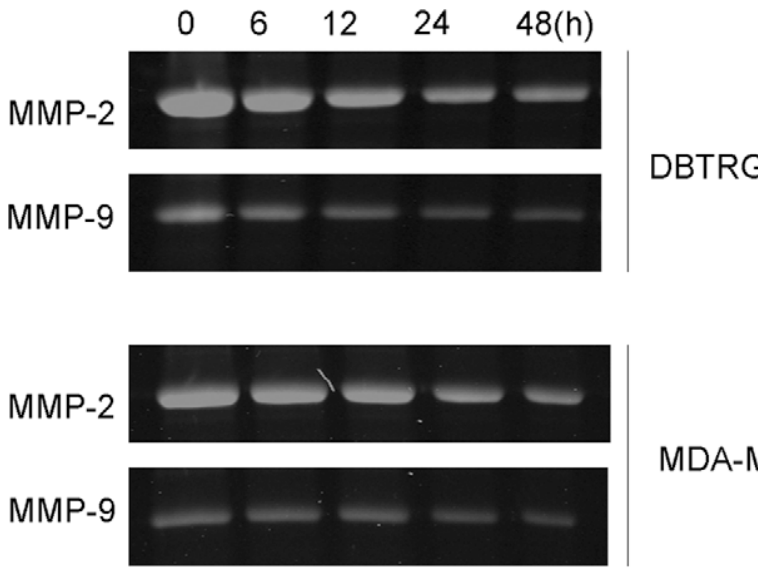

MDA-MB-468

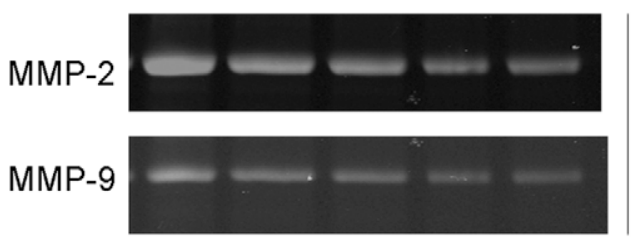

ES-2
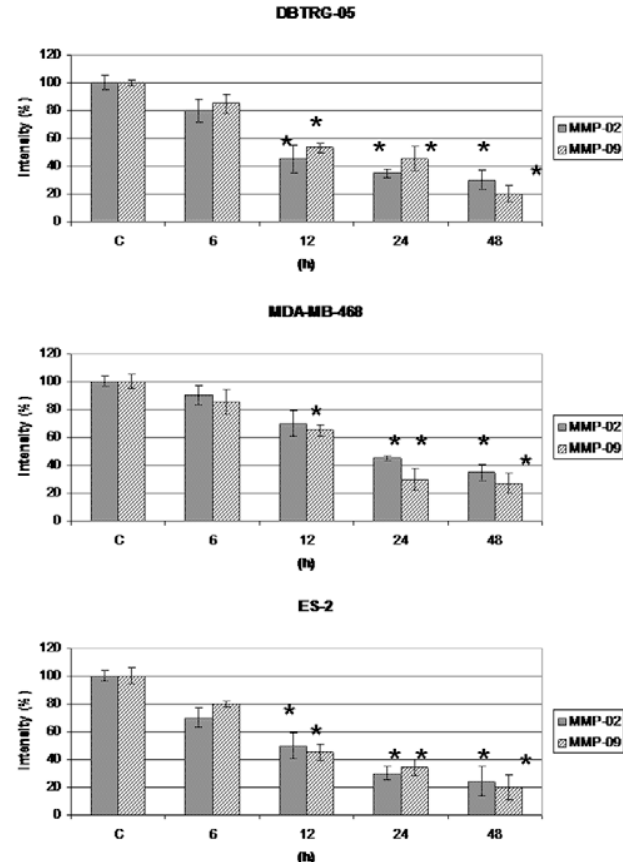

Fig. 7. The effect of GHRH antagonist MIA-602 on the enzymatic activities of MMP-2 and MMP-9 in: (A) DBTRG-05 (B) MDA-MB-468 and (C) ES-2 cell lines. The activities of MMPs were determined by gelatinase zymography after exposure to $1 \mu \mathrm{M}$ MIA-602 with cell supernatants at the indicated time points. The densitometric analysis of MMPs is shown. Each bar represents mean \pm SEM from three independent experiments. ${ }^{*} P<0.05$.

MB-468 estrogen-independent breast cancer and ES-2 clear cell ovarian cancer cell lines.

GHRH antagonists have been found to be effective in the treatment of a variety of experimental tumors xenografted into nude mice [6-8,11,18,27,41-44]. Some studies evaluated the inhibitory effect of earlier GHRH antagonists on the development of metastases in vivo [20,26,27]. We felt that it was of interest to investigate whether a new GHRH antagonist, MIA-602 is able to inhibit the invasive and metastatic activity of DBTRG-05, MDA-MB-468 and ES-2 cancer cell lines. The presence of both pGHRH receptors and SV1 on all three cancer cell lines was demonstrated using Western blot method. Our results showed an intensive pGHRH-R expression at $47.5 \mathrm{kDa}$ and less marked SV1 expression at 39.5 in all three cell lines. The data obtained with DBTRG-05 and MDA-MB-468 cell lines corresponded to earlier investigations [16,17]. MDA-MB468 expressed both receptors at the highest level compared to the other two cell lines. We also demonstrated for the first time the presence of $\mathrm{pGHRH}$ receptors and SV1 on ES- 2 ovarian cancer cells.

The process of tumor cell metastasis is a complex cascade of events, which involves numerous steps such as proliferation, separation of cells from the primary tumor, adherence of the cells to a new location, angiogenesis, the migration of cancer cells into the stroma and the proteolysis of the matrix $[33,37,45]$. It has been reported, that the impediment of local cell proliferation is the critical step in the control of metastases [45]. Previously, improved cell survival following treatment with GHRH has been demonstrated [46]. Accordingly, we investigated the inhibitory ef- fect of MIA-602 on cell proliferation in DBTRG-05, MDAMB-468 and ES-2 cancer cell lines. After 48 h of treatment, $1 \mu \mathrm{M}$ MIA-602 decreased cell viability significantly, with similar results in all three cancer cell lines.

Tumor invasion requires both tumor cell migration and the degradation of the extracellular matrix [35]. Cell motility is one of the pivotal points of metastasis which is necessary for the tumor cell to move through the matrix and enter the circulation so that it can travel to a distant site [37]. In our study, we demonstrated that MIA-602 significantly reduces the chemotaxis of cells across a membrane toward a chemoattractant, like matrigel. Wound-healing assays showed a slower wound-closure following MIA602 treatment, indicating decreased cancer cell motility. Cancer cell adhesion to fibronectin and matrigel was also significantly decreased after treatment with the GHRH antagonist. We also found that ES-2 showed the greatest reduction in cell adhesion and motility after treatment with MIA-602 compared to DBTRG-05 and MDA-MB-468 cell lines.

Besides the alteration of cell adhesion, tumor cell migration involves the disruption of cell-cell connections [33]. E-cadherin, the main component of intercellular adhesion, interacts with cytoskeletal proteins through the catenin complex to preserve the normal function of epithelia $[33,35,47,48]$. The downregulation or loss of E-cadherin in cancer cells, contributes to increased cell adhesion, cell migration and higher tumorigenicity [49,50]. On the other hand, $\beta$-catenin released at the disruption of adherens junctions upregulates the transactivation of $\beta$-cateninresponsive genes, which has been observed in various 
types of cancers [2,51]. We showed that treatment with GHRH antagonist MIA-602 resulted in the increased expression of E-cadherin and the decreased expression of $\beta$-catenin, indicating diminished tumor cell invasion. Different tumors have been reported to express caveolin-1, a constituent of caveolar membrane coats, at a lower level than normal cells [52-54]. When we exposed cancer cells to $1 \mu \mathrm{M}$ MIA-602, the level of caveolin- 1 rose dramatically.

$\mathrm{NF}-\kappa \mathrm{B}$ is a transcriptional factor, which translocates to the nucleus to induce the transcription of proliferation, cell survival and carcinogenesis-associated genes [55,56]. The translocation of NF- $\kappa \mathrm{B}$ to the nucleus was successfully inhibited after treatment with the GHRH antagonist, and $N F-\kappa B$ showed no activation. A downstream target of NF$\kappa \mathrm{B}$ is MMP-2. MMPs are required for the proteolysis of the extracellular matrix, facilitating the migration of cancer cells through the basal membrane [37,57]. They constitute a family of proteases and are able to cleave different substrates of the extracellular matrix [58]. MMPs are secreted in a latent (pro-MMP) form and must be activated to reach their full proteolytic capacity [58]. The overproduction of MMP-s has been associated with tumor growth and metastasis $[59,60]$. To reveal the effect of MIA-602 on cancer cell metastasis, the activity of MMP-2 and MMP-9 proteins was investigated by gelatin zymography. Originally high MMP-2 and MMP-9 activities were visible in the untreated cancer cells' supernatants. After GHRH antagonist treatment, however, their activities diminished significantly in a time-dependent manner. The results found using gelatin zymography were supported by the findings obtained with Western blot. The expression of MMP-2 was significantly reduced after the cells were treated with MIA-602.

In conclusion, our study demonstrates that the new GHRH antagonist, MIA-602 decreases the proliferation, migration, invasion and MMP production in three cancer cell lines representing three different cancers. Our work also shows the interaction between MIA-602 and invasion-associated proteins, E-cadherin, $\beta$-catenin, caveolin1 , NF- $\kappa \mathrm{B}$ and MMP-2, shedding further light on mechanisms of cell invasion and metastasis formation. Collectively, our in vitro results indicate that GHRH antagonists, exemplified by MIA-602 may be potent inhibitors of cancer cell metastasis.

\section{Conflicts of interest}

None declared.

\section{Acknowledgements}

The work described in this paper was supported by the Medical Research Service of the Veterans Affairs Department, University of Miami Miller School of Medicine Departments of Pathology and Medicine, Division of Hematology/Oncology and South Florida Veterans Affairs Foundation for Research and Education (all to AVS). E.P. and Sz.B. are on leave from the Department of Biochemistry and Clinical Chemistry and from the Department of Oncology, University of Pécs, Hungary.

\section{References}

[1] Y.K. Hong, D.S. Chung, Y.A. Joe, Y.J. Yang, K.M. Kim, Y.S. Park, W.K. Yung, J.K. Kang, Efficient inhibition of in vivo human malignant glioma growth and angiogenesis by interferon-beta treatment at early stage of tumor development, Clin. Cancer Res. 6 (2000) 33543360 .

[2] S.A. Vantyghem, S.M. Wilson, C.O. Postenka, W. Al-Katib, A.B. Tuck, A.F. Chambers, Dietary genistein reduces metastasis in a postsurgical orthotopic breast cancer model, Cancer Res. 65 (2005) 3396-3403.

[3] J. von Alten, S. Fister, H. Schulz, V. Viereck, K.H. Frosch, G. Emons, C. Grundker, GnRH analogs reduce invasiveness of human breast cancer cells, Breast Cancer Res. Treat. 100 (2006) 13-21.

[4] H.A. Risch, Hormonal etiology of epithelial ovarian cancer, with a hypothesis concerning the role of androgens and progesterone, J. Natl. Cancer Inst. 90 (1998) 1774-1786.

[5] A.V. Schally, LH-RH analogues: I. Their impact on reproductive medicine, Gynecol. Endocrinol. 13 (1999) 401-409.

[6] H. Kiaris, A.V. Schally, J.L. Varga, Antagonists of growth hormonereleasing hormone inhibit the growth of U-87MG human glioblastoma in nude mice, Neoplasia 2 (2000) 242-250.

[7] Z. Kahan, J.L. Varga, A.V. Schally, Z. Rekasi, P. Armatis, L. Chatzistamou, T. Czompoly, G. Halmos, Antagonists of growth hormone-releasing hormone arrest the growth of MDA-MB-468 estrogen-independent human breast cancers in nude mice, Breast Cancer Res. Treat. 60 (2000) 71-79.

[8] J.B. Engel, G. Keller, A.V. Schally, G.L. Toller, K. Groot, A. Havt, P. Armatis, M. Zarandi, J.L. Varga, G. Halmos, Inhibition of growth of experimental human endometrial cancer by an antagonist of growth hormone-releasing hormone, J. Clin. Endocrinol. Metab. 90 (2005) 3614-3621.

[9] Z. Rekasi, T. Czompoly, A.V. Schally, F. Boldizsar, J.L. Varga, M. Zarandi, T. Berki, R.A. Horvath, P. Nemeth, Antagonist of growth hormone-releasing hormone induces apoptosis in LNCaP human prostate cancer cells through a $\mathrm{Ca}^{2+}$ dependent pathway, Proc. Natl. Acad. Sci. USA 102 (2005) 3435-3440.

[10] A.V. Schally, J.L. Varga, J.B. Engel, Antagonists of growth-hormonereleasing hormone: an emerging new therapy for cancer, Nat. Clin. Pract. Endocrinol. Metab. 4 (2008) 33-43.

[11] A.V. Schally, J.L. Varga, Antagonistic analogs of growth hormonereleasing hormone: new potential antitumor agents, Trends Endocrinol. Metab. 10 (1999) 383-391.

[12] A.V. Schally, A.M. Comaru-Schally, A. Plonowski, A. Nagy, G. Halmos, Z. Rekasi, Peptide analogs in the therapy of prostate cancer, Prostate 45 (2000) 158-166.

[13] A.V. Schally, A.M. Comaru-Schally, A. Nagy, M. Kovacs, K. Szepeshazi, A. Plonowski, J.L. Varga, G. Halmos, Hypothalamic hormones and cancer, Front. Neuroendocrinol. 22 (2001) 248-291.

[14] L.A. Frohman, R.D. Kineman, Growth hormone-releasing hormone and pituitary development, hyperplasia and tumorigenesis, Trends Endocrinol. Metab. 13 (2002) 299-303.

[15] A.V. Schally, K. Szepeshazi, A. Nagy, A.M. Comaru-Schally, G. Halmos, New approaches to therapy of cancers of the stomach, colon and pancreas based on peptide analogs, Cell. Mol. Life Sci. 61 (2004) 1042-1068.

[16] A. Havt, A.V. Schally, G. Halmos, J.L. Varga, G.L. Toller, J.E. Horvath, K. Szepeshazi, F. Koster, K. Kovitz, K. Groot, M. Zarandi, C.A. Kanashiro, The expression of the pituitary growth hormone-releasing hormone receptor and its splice variants in normal and neoplastic human tissues, Proc. Natl. Acad. Sci. USA 102 (2005) 17424-17429.

[17] N. Barabutis, A.V. Schally, Knocking down gene expression for growth hormone-releasing hormone inhibits proliferation of human cancer cell lines, Brit. J. Cancer 98 (2008) 1790-1796.

[18] H. Kiaris, A.V. Schally, J.L. Varga, K. Groot, P. Armatis, Growth hormone-releasing hormone: an autocrine growth factor for small cell lung carcinoma, Proc. Natl. Acad. Sci. USA 96 (1999) 1489414898.

[19] H. Kiaris, M. Koutsilieris, A. Kalofoutis, A.V. Schally, Growth hormone-releasing hormone and extra-pituitary tumorigenesis: therapeutic and diagnostic applications of growth hormonereleasing hormone antagonists, Expert Opin. Investig. Drugs 12 (2003) 1385-1394.

[20] I. Chatzistamou, A.V. Schally, J.L. Varga, K. Groot, R. Busto, P. Armatis, G. Halmos, Inhibition of growth and metastases of MDA-MB-435 human estrogen-independent breast cancers by an antagonist of growth hormone-releasing hormone, Anticancer Drugs 12 (2001) 761-768.

[21] I. Chatzistamou, A.V. Schally, J.L. Varga, K. Groot, P. Armatis, R. Busto, G. Halmos, Antagonists of growth hormone-releasing hormone and 
somatostatin analog RC-160 inhibit the growth of the OV-1063 human epithelial ovarian cancer cell line xenografted into nude mice, J. Clin. Endocrinol. Metab. 86 (2001) 2144-2152.

[22] R. Braczkowski, A.V. Schally, A. Plonowski, J.L. Varga, K. Groot, M. Krupa, P. Armatis, Inhibition of proliferation in human MNNG/HOS osteosarcoma and SK-ES-1 Ewing sarcoma cell lines in vitro and in vivo by antagonists of growth hormone-releasing hormone: effects on insulin-like growth factor II, Cancer 95 (2002) 1735-1745.

[23] R. Busto, A.V. Schally, J.L. Varga, M.O. Garcia-Fernandez, K. Groot, P. Armatis, K. Szepeshazi, The expression of growth hormone-releasing hormone (GHRH) and splice variants of its receptor in human gastroenteropancreatic carcinomas, Proc. Natl. Acad. Sci. USA 99 (2002) 11866-11871.

[24] P. Zeitler, G. Siriwardana, Antagonism of endogenous growth hormone-releasing hormone (GHRH) leads to reduced proliferation and apoptosis in MDA231 breast cancer cells, Endocrine 18 (2002) 85-90.

[25] L.B. Jaeger, W.A. Banks, J.L. Varga, A.V. Schally, Antagonists of growth hormone-releasing hormone cross the blood-brain barrier: a potential applicability to treatment of brain tumors, Proc. Natl. Acad. Sci. USA 102 (2005) 12495-12500.

[26] A. Stangelberger, A.V. Schally, J.L. Varga, M. Zarandi, K. Szepeshazi, P. Armatis, G. Halmos, Inhibitory effect of antagonists of bombesin and growth hormone-releasing hormone on orthotopic and intraosseous growth and invasiveness of PC-3 human prostate cancer in nude mice, Clin. Cancer Res. 11 (2005) 49-57.

[27] G. Halmos, A.V. Schally, J.L. Varga, A. Plonowski, Z. Rekasi, T. Czompoly, Human renal cell carcinoma expresses distinct binding sites for growth hormone-releasing hormone, Proc. Natl. Acad. Sci. USA 97 (2000) 10555-10560.

[28] S. Buchholz, A.V. Schally, J.B. Engel, F. Hohla, E. Heinrich, F. Koester J.L. Varga, G. Halmos, Potentiation of mammary cancer inhibition by combination of antagonists of growth hormone-releasing hormone with docetaxel, Proc. Natl. Acad. Sci. USA 104 (2007) 1943-1946.

[29] S. Bellyei, A. Szigeti, A. Boronkai, E. Pozsgai, E. Gomori, B. Melegh, T. Janaky, Z. Bognar, E. Hocsak, B. Sumegi, F. Gallyas Jr., Inhibition of cell death by a novel $16.2 \mathrm{kD}$ heat shock protein predominantly via Hsp90 mediated lipid rafts stabilization and Akt activation pathway, Apoptosis 12 (2007) 97-112.

[30] Z. Rekasi, T. Czompoly, A.V. Schally, G. Halmos, Isolation and sequencing of cDNAs for splice variants of growth hormonereleasing hormone receptors from human cancers, Proc. Natl. Acad. Sci. USA 97 (2000) 10561-10566.

[31] S. Schulz, C. Rocken, Immunocytochemical localisation of plasma membrane GHRH receptors in human tumours using a novel antipeptide antibody, Eur. J. Cancer 42 (2006) 2390-2396.

[32] H. Kiaris, A.V. Schally, R. Busto, G. Halmos, S. Artavanis-Tsakonas, J.L. Varga, Expression of a splice variant of the receptor for GHRH in 3T3 fibroblasts activates cell proliferation responses to GHRH analogs, Proc. Natl. Acad. Sci. USA 99 (2002) 196-200.

[33] J. Yu, H. Qian, Y. Li, Y. Wang, X. Zhang, X. Liang, M. Fu, C. Lin, Arsenic trioxide (As2O3) reduces the invasive and metastatic properties of cervical cancer cells in vitro and in vivo, Gynecol. Oncol. 106 (2007) 400-406.

[34] K.H. Shen, S.H. Hung, L.T. Yin, C.S. Huang, C.H. Chao, C.L. Liu, Y.W. Shih, Acacetin, a flavonoid, inhibits the invasion and migration of human prostate cancer DU145 cells via inactivation of the p38 MAPK signaling pathway, Mol. Cell. Biochem. (2009).

[35] F. Su, H. Li, C. Yan, B. Jia, Y. Zhang, X. Chen, Depleting MEKK1 expression inhibits the ability of invasion and migration of human pancreatic cancer cells, J. Cancer Res. Clin. Oncol. (2009).

[36] M. Li, J. Xie, L. Cheng, B. Chang, Y. Wang, X. Lan, D. Zhang, Y. Yin, N. Cheng, Suppression of invasive properties of colorectal carcinoma SW480 cells by 15-hydroxyprostaglandin dehydrogenase gene, Cancer Invest. 26 (2008) 905-912.

[37] T.L. Larkins, M. Nowell, S. Singh, G.L. Sanford, Inhibition of cyclooxygenase-2 decreases breast cancer cell motility, invasion and matrix metalloproteinase expression, BMC Cancer 6 (2006) 181.

[38] J.M. Arencibia, A.V. Schally, G. Halmos, A. Nagy, H. Kiaris, In vitro targeting of a cytotoxic analog of luteinizing hormone-releasing hormone AN-207 to ES-2 human ovarian cancer cells as demonstrated by microsatellite analyses, Anticancer Drugs 12 (2001) 71-78

[39] A. Jemal, R. Siegel, E. Ward, Y. Hao, J. Xu, T. Murray, M.J. Thun, Cancer statistics, 2008, CA Cancer J. Clin. 58 (2008) 71-96.
[40] M. Arya, S.R. Bott, I.S. Shergill, H.U. Ahmed, M. Williamson, H.R. Patel, The metastatic cascade in prostate cancer, Surg. Oncol. 15 (2006) 117-128.

[41] A.V. Schally, J.L. Varga, Antagonists of growth hormone-releasing hormone in oncology, Comb. Chem. High Throughput Screen. 9 (2006) 163-170.

[42] K. Szepeshazi, A.V. Schally, K. Groot, P. Armatis, G. Halmos, F. Herbert, B. Szende, J.L. Varga, M. Zarandi, Antagonists of growth hormone-releasing hormone (GH-RH) inhibit IGF-II production and growth of HT-29 human colon cancers, Brit. J. Cancer 82 (2000) 1724-1731.

[43] K. Szepeshazi, A.V. Schally, K. Groot, P. Armatis, F. Hebert, G. Halmos, Antagonists of growth hormone-releasing hormone (GH-RH) inhibit in vivo proliferation of experimental pancreatic cancers and decrease IGF-II levels in tumours, Eur. J. Cancer 36 (2000) 128136.

[44] A. Plonowski, J.L. Varga, A.V. Schally, M. Krupa, K. Groot, G. Halmos, Inhibition of PC-3 human prostate cancers by analogs of growth hormone-releasing hormone (GH-RH) endowed with vasoactive intestinal peptide (VIP) antagonistic activity, Int. J. Cancer 98 (2002) 624-629.

[45] L.H. Wei, K.P. Lai, C.A. Chen, C.H. Cheng, Y.J. Huang, C.H. Chou, M.L Kuo, C.Y. Hsieh, Arsenic trioxide prevents radiation-enhanced tumor invasiveness and inhibits matrix metalloproteinase-9 through downregulation of nuclear factor kappaB, Oncogene 24 (2005) 390-398.

[46] R. Granata, L. Trovato, M.P. Gallo, S. Destefanis, F. Settanni, F. Scarlatti, A. Brero, R. Ramella, M. Volante, J. Isgaard, R. Levi, M. Papotti, G. Alloatti, E. Ghigo, Growth hormone-releasing hormone promotes survival of cardiac myocytes in vitro and protects against ischaemia-reperfusion injury in rat heart, Cardiovasc. Res. 83 (2009) 303-312.

[47] C. Jamora, E. Fuchs, Intercellular adhesion, signalling and the cytoskeleton, Nat. Cell. Biol. 4 (2002) E101-108.

[48] D.L. Rimm, E.R. Koslov, P. Kebriaei, C.D. Cianci, J.S. Morrow, Alpha $1(\mathrm{E})$-catenin is an actin-binding and -bundling protein mediating the attachment of F-actin to the membrane adhesion complex, Proc Natl. Acad. Sci. USA 92 (1995) 8813-8817.

[49] D. Chin, G.M. Boyle, A.J. Kane, D.R. Theile, N.K. Hayward, P.G. Parson, W.B. Coman, Invasion and metastasis markers in cancers, Brit. J. Plast. Surg. 58 (2005) 466-474.

[50] K. Vleminckx, L. Vakaet Jr., M. Mareel, W. Fiers, F. van Roy, Genetic manipulation of E-cadherin expression by epithelial tumor cells reveals an invasion suppressor role, Cell 66 (1991) 107-119.

[51] P.J. Morin, Beta-catenin signaling and cancer, Bioessays 21 (1999) 1021-1030.

[52] M. Bagnoli, A. Tomassetti, M. Figini, S. Flati, V. Dolo, S. Canevari, S. Miotti, Down modulation of caveolin-1 expression in human ovarian carcinoma is directly related to alpha-folate receptor overexpression, Oncogene 19 (2000) 4754-4763.

[53] F.C. Bender, M.A. Reymond, C. Bron, A.F. Quest, Caveolin-1 levels are down-regulated in human colon tumors, and ectopic expression of caveolin-1 in colon carcinoma cell lines reduces cell tumorigenicity, Cancer Res. 60 (2000) 5870-5878.

[54] K. Wiechen, C. Sers, A. Agoulnik, K. Arlt, M. Dietel, P.M. Schlag, U. Schneider, Down-regulation of caveolin-1, a candidate tumor suppressor gene, in sarcomas, Am. J. Pathol. 158 (2001) 833-839.

[55] A.S. Baldwin Jr., The NF-kappa B and I kappa B proteins: new discoveries and insights, Annu. Rev. Immunol. 14 (1996) 649683.

[56] A. Rossi, P. Kapahi, G. Natoli, T. Takahashi, Y. Chen, M. Karin, M.G. Santoro, Anti-inflammatory cyclopentenone prostaglandins are direct inhibitors of IkappaB kinase, Nature 403 (2000) 103-108.

[57] S. Curran, G.I. Murray, Matrix metalloproteinases: molecular aspects of their roles in tumour invasion and metastasis, Eur. J. Cancer 36 (2000) 1621-1630

[58] P.A. Snoek-van Beurden, J.W. Von den Hoff, Zymographic techniques for the analysis of matrix metalloproteinases and their inhibitors Biotechniques 38 (2005) 73-83.

[59] L.M. Coussens, B. Fingleton, L.M. Matrisian, Matrix metalloproteinase inhibitors and cancer: trials and tribulations, Science 295 (2002) 2387-2392.

[60] M.J. Duffy, T.M. Maguire, A. Hill, E. McDermott, N. O'Higgins, Metalloproteinases: role in breast carcinogenesis, invasion and metastasis, Breast Cancer Res. 2 (2000) 252-257. 